\title{
Bim and $\mathrm{Mcl}-1$ exert key roles in regulating JAK2 ${ }^{\mathrm{V} 617 \mathrm{~F}}$ cell survival
}

Joëlle Rubert ${ }^{\dagger}$, Zhiyan Qian ${ }^{\dagger}$, Rita Andraos, Daniel A Guthy, Thomas Radimerski

\begin{abstract}
Background: The JAK2 ${ }^{\mathrm{V} 617 \mathrm{~F}}$ mutation plays a major role in the pathogenesis of myeloproliferative neoplasms and is found in the vast majority of patients suffering from polycythemia vera and in roughly every second patient suffering from essential thrombocythemia or from primary myelofibrosis. The V617F mutation is thought to provide hematopoietic stem cells and myeloid progenitors with a survival and proliferation advantage. It has previously been shown that activated JAK2 promotes cell survival by upregulating the anti-apoptotic STAT5 target gene Bcl$x \mathrm{~L}$. In this study, we have investigated the role of additional apoptotic players, the pro-apoptotic protein Bim as well as the anti-apoptotic protein Mcl-1.
\end{abstract}

Methods: Pharmacological inhibition of JAK2/STAT5 signaling in JAK2 ${ }^{\mathrm{V} 617 \mathrm{~F}}$ mutant SET-2 and MB-02 cells was used to study effects on signaling, cell proliferation and apoptosis by Western blot analysis, WST-1 proliferation assays and flow cytometry. Cells were transfected with siRNA oligos to deplete candidate pro- and anti-apoptotic proteins. Co-immunoprecipitation assays were performed to assess the impact of JAK2 inhibition on complexes of pro- and anti-apoptotic proteins.

Results: Treatment of JAK2 ${ }^{\mathrm{V} 617 \mathrm{~F}}$ mutant cell lines with a JAK2 inhibitor was found to trigger Bim activation. Furthermore, Bim depletion by RNAi suppressed JAK2 inhibitor-induced cell death. Bim activation following JAK2 inhibition led to enhanced sequestration of $\mathrm{Mcl}-1$, besides BCl-xL. Importantly, Mcl-1 depletion by RNAi was sufficient to compromise JAK2 ${ }^{\mathrm{V} 617 \mathrm{~F}}$ mutant cell viability and sensitized the cells to JAK2 inhibition.

Conclusions: We conclude that Bim and $\mathrm{MCl}-1$ have key opposing roles in regulating JAK2 ${ }^{\mathrm{V} 617 \mathrm{~F}}$ cell survival and propose that inactivation of aberrant JAK2 signaling leads to changes in Bim complexes that trigger cell death. Thus, further preclinical evaluation of combinations of JAK2 inhibitors with $\mathrm{BCl}-2$ family antagonists that also tackle $\mathrm{MCl}-1$, besides $\mathrm{BCl}-\mathrm{xL}$, is warranted to assess the therapeutic potential for the treatment of chronic myeloproliferative neoplasms.

\section{Background}

The somatic activating JAK2 ${ }^{\mathrm{V} 617 \mathrm{~F}}$ mutation is found in nearly every patient with the chronic myeloproliferative neoplasm (cMPN) polycythemia vera (PV) and roughly half of those patients affected by essential thrombocythemia (ET) and primary myelofibrosis (PMF) [1]. At the molecular level, it is thought that the V617F mutation in the JAK2 pseudokinase alleviates some of the negative regulation that this domain normally elicits on the kinase domain [2], allowing for increased kinase autoactivation [3]. Clinical trials with JAK inhibitors in

\footnotetext{
* Correspondence: thomas.radimerski@novartis.com

+ Contributed equally

Disease Area Oncology, Novartis Institutes for BioMedical Research, Basel, Switzerland
}

primary myelofibrosis patients are underway and have shown rapid suppression of splenomegaly and improvement of constitutional symptoms [4]. However, up to now effects on mutant allele burden have been modest and bone marrow fibrosis appears to persist [5], warranting continued pre-clinical and clinical research in order to improve therapeutic outcome of JAK inhibitors in cMPNs. Mutant JAK2 ${ }^{\mathrm{V} 617 \mathrm{~F}}$, which arises at the level of the hematopoietic stem cell [6], likely provides progenitor cells with both a proliferation and a survival advantage [7]. Hence, a potential avenue for enhanced JAK2 ${ }^{\mathrm{V} 617 \mathrm{~F}}$ cell killing by JAK2 inhibitors may lie in simultaneous perturbation of survival mechanisms. Importantly, several studies have found that the antiapoptotic Bcl-2 family member Bcl-xL plays a role in 
PV erythroblast survival $[8,9]$. Along these lines, Bcl-xL depletion induced apoptosis in JAK2 ${ }^{\mathrm{V} 617 \mathrm{~F}}$ mutant cells and the $\mathrm{BH} 3$ ( $\mathrm{Bcl}$-2-homology domain 3)-mimetic ABT737 was shown to preferentially kill JAK2 $2^{\mathrm{V} 617 \mathrm{~F}}$ mutant PV erythroid precursors as compared to healthy subject erythroblasts $[9,10]$. The BH3-only pro-apoptotic protein Bad has been implicated in regulating JAK2 $2^{\mathrm{V} 617 \mathrm{~F}}$ mutant cell survival [10] and engages anti-apoptotic Bcl-2, Bcl$\mathrm{xL}$ and $\mathrm{Bcl}-\mathrm{w}$, but not Mcl-1 [11]. Mcl-1 protein is normally short-lived due to rapid proteasome-mediated destruction but contributes to resistance to cell-death stimuli if its levels are elevated $[12,13]$.

In this study we focused on elucidating potential roles of pro-apoptotic Bim and anti-apoptotic Mcl-1 in regulating JAK2 ${ }^{\mathrm{V} 617 \mathrm{~F}}$ mutant cell survival. In contrast to Bad, Bim can engage all Bcl-2 pro-survival family members, including Mcl-1 [11]. Both Bim and Mcl-1 were readily detectable in JAK2 ${ }^{\mathrm{V} 617 \mathrm{~F}}$ mutant cell lines and co-immunoprecipitated. JAK2 inhibition led to changes in BimEL Ser69 phosphorylation, along with a drop in total Mcl-1 levels and concomitant induction of programmed cell death. In support of a key role in regulating JAK2 ${ }^{\mathrm{V} 617 \mathrm{~F}}$ cell survival, Mcl-1 depletion by RNAi was found to severely compromise cell viability and sensitized cells to JAK2 inhibition. Taken together, we show that Mcl-1 appears to be critical for JAK2 $2^{\mathrm{V} 617 \mathrm{~F}}$ mutant cell survival, and corroborate that cell death induced by JAK2 inhibition requires Bim activation. Our findings suggest that combinations of JAK2 inhibitors with Bcl-2 family antagonists that tackle both Bcl-xL and Mcl-1 merit further preclinical evaluation of the therapeutic potential for the treatment of cMPNs.

\section{Methods}

\section{Compounds and formulations}

NVP-BSK805 (free base) was synthesized internally [14], $10 \mathrm{mM}$ stock solutions were prepared in dimethyl sulfoxide (DMSO) and aliquots were stored at $-20^{\circ} \mathrm{C}$ until use. The ethyl-ester of the pan-caspase inhibitor Z-VAD-FMK was synthesized internally. UO126 (\# 1144, Tocris Bioscience, Ellisville, MO, USA) was prepared as a $10 \mathrm{mM}$ stock solution in DMSO and stored at $-20^{\circ} \mathrm{C}$ until use. Obatoclax mesylate (\# S1057, Selleck Chemicals, Houston, TX, USA) was prepared as a $10 \mathrm{mM}$ stock solution in DMSO and stored at $-20^{\circ} \mathrm{C}$ until use.

\section{Cell culture}

SET-2 cells (generously provided by Prof. Hans Drexler, DSMZ, Braunschweig, Germany) were cultured in standard RPMI medium supplemented with $10 \%$ of fetal calf serum (FCS), $2 \mathrm{mM}$ L-glutamine and $1 \%(\mathrm{v} / \mathrm{v})$ penicillin/streptomycin. MB-02 cells (generously provided by Prof. Doris Morgan, Drexel University, Philadelphia, PA, USA) were grown in RPMI medium as described above, supplemented with $10 \mathrm{ng} / \mathrm{ml}$ recombinant human GM-CSF (granulocyte-macrophage colony-stimulating factor), $10 \mathrm{ng} / \mathrm{ml}$ recombinant human SCF (stem cell factor) and $10 \mathrm{mM}$ sodium pyruvate. TF-1 cells (American Type Culture Collection) were cultured in RPMI medium, supplemented with $20 \%$ of fetal bovine serum, $1 \mathrm{mM} \mathrm{L}$-glutamine, $5 \mathrm{~g} / \mathrm{l}$ sodium bicarbonate, $10 \mathrm{mM}$ HEPES, $1 \mathrm{mM}$ sodium pyruvate, $4.5 \mathrm{~g} / \mathrm{l} \mathrm{D}$-glucose, $1 \%$ (v/v) penicillin/streptomycin and $2 \mathrm{ng} / \mathrm{ml}$ GM-CSF.

\section{RNA interference}

The following stealth ${ }^{\mathrm{TM}}$ RNAi oligonucleotides (Invitrogen, Carlsbad, CA, USA) were used; BAD: duplex $15^{\prime}$ GCUCCGGAGGAUGAGUGACGAGUUU-3', duplex 2 5'-GGACUCCUUUAAGAAGGGACUUCCU-3' and duplex 3 5'-UCUUCCAGUCCUGGUGGGAUCGGAA3'; Bim: duplex 1 5'-UGAGUGUGACCGAGAAGG UAGACAA-3', duplex 2 5'-CAUGAGUUGUGACAAAUCAACACAA-3' and duplex 3 5'-CACGAAUGGUUAUCUUACGACUGUU-3'; Mcl-1: duplex 1 5'GAAAGUAUCACAGACGUUCUCGUAA-3', duplex 2 5'-CGGGACUGGCUAGUUAAACAAAGAG-3' and duplex 3 5'-GGUUUGUGGAGUUCUUCCAUGUAGA3', and a non-targeting control stealth ${ }^{\mathrm{TM}}$ RNAi oligo 5'GAUGAAGGGAGGGUGUACCAACUUA-3'. Cells were transfected with RNAi oligonucleotides using Nucleofactor ${ }^{\mathrm{TM}}$ Solution V (Amaxa GmbH, Cologne, Germany) and the Amaxa system according to the instructions of the manufacturer.

\section{Real-Time Quantitative PCR}

Mcl-1 mRNA levels were determined by real-time quantitative PCR using the Applied Biosystems Taqman Gene Expression kit (\# Hs03043899_m1, Applied Biosystems, Carlsbad, CA, USA). Total RNA from cells was isolated with the RNeasy Mini Kit (\# 74104, Qiagen, Hilden, Germany), accompanied by an on-column DNase (\# 79254, Qiagen) digestion. Expression levels of the housekeeping gene GAPDH (\# 4310884E, Applied Biosystems) were also measured as an endogenous normalization control. $\mathrm{Mcl}-1$ and GAPDH signals were measured with FAM (6-carboxy-fluorescein) and VIC fluorescent reporter dye labeling, respectively. The volume of each reaction was $10 \mu \mathrm{l}$ per well (384-well plate), which consisted of $5 \mu \mathrm{l} 2 \times$ reaction buffer and $0.05 \mu \mathrm{l} 200 \times$ Euroscript RT (reverse transcriptase) enzyme and RNase inhibitor mix from the one-step RTqPCR MasterMix Plus (\# RT-QPRT-032X, Eurogentec, Seraing, Belgium), $0.5 \mu \mathrm{l} 20 \times$ Taqman Gene Expression mix together with $2 \mu \mathrm{l}$ of $50 \mathrm{ng}$ RNA as amplification template. The ROX reference dye was present in the RT-qPCR reaction buffer. RT-qPCR was carried out on the ABI 7900HT Fast Real-Time PCR system (Applied Biosystems, SDS2.3 software). The reaction mixtures 
were incubated at $48^{\circ} \mathrm{C}$ for 30 minutes, during which the reverse transcription took place, $95^{\circ} \mathrm{C}$ for 10 minutes to activate HotGoldStar DNA polymerase (Eurogentec), followed by 40 cycles at $95^{\circ} \mathrm{C}$ for 15 seconds and $60^{\circ} \mathrm{C}$ for 1 minute. Samples were measured in triplicate. Cycle threshold $(\mathrm{Ct})$ values were used to determine the relative amounts of $\mathrm{Mcl}-1$ and GAPDH mRNA levels in the samples. $2^{-\mathrm{Ct}} \mathrm{Mcl}-1$ values were computed and normalized to mean $2^{\text {-Ct }}$ GAPDH values. $M c l-1$ mRNA levels were depicted as fold change compared to DMSO vehicle control by dividing normalized $2^{-\mathrm{Ct}}$ values of compound treated samples by those of vehicle treated samples.

\section{Western blotting}

Cells were extracted in lysis buffer (50 mM HEPES pH 7.4, $150 \mathrm{mM} \mathrm{NaCl}, 25 \mathrm{mM} \beta$-glycerophosphate, $25 \mathrm{mM}$ $\mathrm{NaF}, 5 \mathrm{mM}$ EGTA, $1 \mathrm{mM}$ EDTA, $15 \mathrm{mM}$ pyrophosphate PPI, supplemented freshly with $1 \%$ Nonidet P-40, $1 \mathrm{x}$ protease inhibitor cocktail (Complete Mini, Roche), $1 \mathrm{mM}$ DTT, $0.2 \mathrm{mM}$ sodium-vanadate and $1 \mathrm{mM}$ PMSF) by passing through a $1 \mathrm{ml}$ syringe connected to a 23-gauge needle. Cell debris were pelleted by centrifugation. Typically, $20 \mu \mathrm{g}$ of protein lysates were resolved by NuPAGE Novex 4-12\% Bis-Tris Midi Gels (Invitrogen, Carlsbad, CA, USA) and transferred to PVDF membranes by semi-dry blotting. The following antibodies were used to probe blots: Anti-cleaved caspase 3 (\# 9664), 7 (\# 9491), 8 (\# 9496), 9 (\# 9501), Bad (\#9292), Bak (\# 3814), Bax (\# 2772), Bcl-xL (\# 2762), Bim (\# 2933), phospho-Bim (Ser55 (Homo sapiens: Ser59) (\# 4550), phospho-Bim (Ser69) (\# 4581), ERK1/2 (\# 9102), phospho-ERK1/2 (Thr201/Tyr204) (9101), Mcl-1 (\# 4572), PARP (\# 9542), phospho-STAT5 (\# 9359) and phosphotyrosine (\# 9411) were from Cell Signaling Technology (Beverly, MA, USA). Anti-Bim (\# 202000) from Calbiochem (San Diego, CA, USA) was also used. The STAT5 antibody (\# sc-835) was from Santa Cruz Biotechnology (Santa Cruz, CA, USA). The $\beta$-tubulin (\# T4026) and Mcl-1 (\# AAP-240) antibodies were from Sigma (St. Louis, MO, USA) and Assay Designs (Ann Arbor, MI, USA), respectively. Antibodies were typically incubated overnight at $4{ }^{\circ} \mathrm{C}$ followed by washes and incubation with the corresponding HRP-conjugated secondary antibodies. Immunoreactive bands were revealed with enhanced chemiluminescence reagents.

Immunoprecipitation and co-immunoprecipitation assays Cells were extracted either in CHAPS lysis buffer [15] or in Triton/glycerol ("TG") lysis buffer [16] (the latter for Bcl-xL/Bax co-immunoprecipitation studies), lysates were kept on ice and protein content was determined by Bradford assay. Immediately thereafter, typically $500 \mu \mathrm{g}$ total protein input were subject to immunoprecipitation using the following antibodies: Anti-Bim (\# 2933), antiBcl-xL (\# 2762) and anti-Bax (\# 2772) were from Cell Signaling Technology (Beverly, MA, USA), anti-Mcl-1 (\# 559027) from BD Biosciences (Franklin Lakes, NJ, USA). Co-immunoprecipitation assays were carried out using $1.5 \mathrm{ml}$ Eppendorf protein LoBind Tubes (\# 0030 108.116, Eppendorf, Hamburg, Germany). Bound fractions were released by heating at $70^{\circ} \mathrm{C}$ for 10 minutes in $20 \mu \mathrm{l}$ NuPAGE LDS sample buffer. The supernatant containing the bound fraction was resolved by gradient gel electrophoresis and transferred to PVDF membranes for Western blot analysis as described above.

\section{Proliferation assays}

Anti-proliferative activity of the JAK2 inhibitor NVPBSK805 was determined by incubating SET-2 cells or MB-02 cells with an 8 point concentration range of compound and cell proliferation relative to DMSO treated cells was measured (typically after 72 hours for SET- 2 cells and after 96 hours for MB-02 cells, unless specified otherwise) using the colorimetric WST-1 (Roche Diagnostics GmbH, Penzberg, Germany) cell viability readout. Of each triplicate treatment the mean was calculated and these data were plotted in XLfit 4 (XLfit 4, ID Business Solutions Ltd, Guildford, Surrey, UK) to determine the respective half-maximal growthinhibitory concentration $\left(\mathrm{GI}_{50}\right)$ values.

\section{Flow cytometry}

Cultured cells were collected after treatments, washed once with PBS and resuspended in propidium iodide buffer (1 mM sodium citrate $(\mathrm{pH} 4.0), 1.5 \mathrm{mM} \mathrm{NaCl}$, $5 \mathrm{mM}$ EDTA, $5 \mathrm{mM}$ EGTA, 0.1\% NP40, $4 \mu \mathrm{g}$ of propidium iodide $/ \mathrm{ml}$ and $80 \mu \mathrm{g} / \mathrm{ml}$ of $\mathrm{RNaseA}$ in PBS). After 30 minutes of incubation in the dark on ice, cellular DNA content was measured with a BD FACSCalibur flow cytometer (BD Biosciences, San Jose, CA, USA). For detection of activated Bak, cells were washed in PBS and then fixed at RT for 5 minutes in $0.25 \%$ paraformaldehyde (diluted in PBS). After washing twice with PBS the cell pellet was resuspended in $200 \mu \mathrm{l}$ PBS containing 0.1\% digitonin (\# D141, Sigma) and then $10 \mu$ mouse anti-Bak antibody (\# AM03 (Ab-1), Calbiochem) were added followed by incubation on ice for 30 minutes. After washing twice with PBS the cell pellet was resuspended in $100 \mu \mathrm{l}$ PBS and incubated at room temperature in the dark for 40 minutes with $5 \mu \mathrm{l}$ fluorescein isothiocyanate (FITC)-conjugated antimouse antibody (\# sc-2010, Santa Cruz) followed by two washes with PBS and flow cytometry analysis. The shifts in fluorescent channel 1-height (FL1-H) fluorescence intensity compared to DMSO vehicle controls were quantified and represented as fold change over DMSO control. 


\section{Statistical analysis}

The $t$-test was conducted to determine statistical significance between two groups. The significance level was set at $\mathrm{p}<0.05$. Statistical analysis was performed using SigmaPlot v11.0 (Systat Software Inc, Chicago, IL, USA).

\section{Results}

NVP-BSK805 JAK2 inhibitor triggered cell death requires activation of caspase cascades and is overcome by caspase inhibition

We have previously shown that the JAK2 inhibitor tool compound NVP-BSK805 blunts constitutive STAT5 phosphorylation in JAK2 ${ }^{\mathrm{V} 617 \mathrm{~F}}$ mutant cell lines, reduces Bcl-xL levels and blocks cell proliferation with concomitant induction of cell death [17]. To corroborate that NVP-BSK805 induces programmed cell death in JAK2 $2^{\mathrm{V} 617 \mathrm{~F}}$ mutant cell lines, we assessed if apoptosis would be overcome by pharmacological inhibition of caspases. To this end we used SET-2 and MB-02 cells, which bear mutated JAK2 ${ }^{\mathrm{V} 617 \mathrm{~F}}$ and have been derived from leukemia patients with a previous history of essential thrombocythemia and myelofibrosis, respectively $[18,19]$. SET-2 and MB-02 cells were pretreated for 1 hour with increasing concentrations of a pan-caspase inhibitor, followed by treatment with $0.5 \mu \mathrm{M}$ NVP-BSK805 for 24 hours. In both cell lines the caspase inhibitor elicited a concentration-dependent suppression of JAK2 inhibitor-triggered PARP cleavage (Figure 1A and $1 \mathrm{~B})$. A concentration of $200 \mu \mathrm{M}$ of the caspase inhibitor was found to completely counteract PARP-cleavage as a result of JAK2 inhibition in both cell lines. Both SET-2 and MB-02 cells respond sensitively to JAK2 inhibition by NVP-BSK805 in cell proliferation assays over 72 and 96 hours, respectively [17], and this anti-proliferative response is blunted by caspase inhibition (Figure 1C and 1D).

Apoptosis is executed by caspase cascades of the socalled intrinsic and extrinsic pathways that activate caspase 9 and 8, respectively [20]. In order to assess (i) the timing of caspase induction following JAK2 inhibition and (ii) dissect the caspase cascades triggering cell death, SET-2 and MB-02 cells lines were treated with NVP-BSK805 and extracted at different points in time. In both cell lines PARP cleavage became evident at the 16 hours time point, coinciding with the detection of cleaved caspases 9 and 8, as well as cleaved effector caspases 3 and 7 (Figure 2). These results imply that programmed cell death triggered by JAK 2 inhibition in the JAK2 ${ }^{\mathrm{V} 617 \mathrm{~F}}$ mutant cell lines involves both the intrinsic and extrinsic pathways.

\section{Key role of Bim in JAK2 inhibitor induced apoptosis in JAK2 ${ }^{\mathrm{V} 617 \mathrm{~F}}$ cells}

To gain more insights into the apoptotic players involved in triggering the caspases of the intrinsic pathway in $\mathrm{JAK} 2^{\mathrm{V} 617 \mathrm{~F}}$ cell lines, we tested the impact of Bad depletion on JAK2 inhibitor-induced apoptosis. Bad and Bcl-xL have previously been shown to play a role in SET-2 cell survival [10]. In agreement with these earlier reports, Bad depletion by RNAi partially suppressed apoptosis induction in SET-2 cells, as assessed by PARP cleavage and measuring the sub-G1 cell fraction by flow cytometry, following JAK2 inhibition (Figure 3A and $3 \mathrm{C})$. However, in MB-02 cells Bad depletion only modestly suppressed NVP-BSK805-induced cell death (Figure $4 \mathrm{~A}$ and $4 \mathrm{C}$ ). Intrigued by this finding, we explored the role of Bim, another BH3-only protein, in JAK2 inhibitor-induced apoptosis. In both cell lines, Bim levels were readily detected at baseline and strongly reduced following RNAi (Figure 2, 3A and 4A). In both SET-2 and MB02 cells Bim-EL was the predominant isoform expressed (Figure $3 \mathrm{~B}$ and $4 \mathrm{~B}$ ). Importantly, Bim-depleted SET-2 and MB-02 cells were largely resistant to cell death by NVP-BSK805 (Figure 3C and 4C). Similarly, Will et al. recently reported that shRNAmediated Bim depletion suppressed apoptosis induced by JAK2 inhibition in HEL cells [21]. In SET-2 cell proliferation assays, Bim depletion resulted in a three-fold increase in the $\mathrm{GI}_{50}$ (half-maximal growth-inhibitory concentration) of NVP-BSK805 (Figure 3D). In agreement with a recent report [21], these findings corroborate a crucial role for Bim in the execution of cell death in JAK2 $2^{\mathrm{V} 617 \mathrm{~F}}$ mutant cells.

\section{JAK2 inhibition in JAK2 ${ }^{\mathrm{V} 617 \mathrm{~F}}$ cells modulates the post- translational modification of Bim and levels of $\mathrm{Mcl}-1$} Upon incubation of JAK2 $2^{\mathrm{V} 617 \mathrm{~F}}$ mutant cell lines with NVP-BSK805, we noticed that Mcl-1 levels started to drop at the 16 hours time point, paralleling the activation of caspases and PARP cleavage (Figure 2). Mcl-1 is a protein with a relatively short half-life and has been shown to be dynamically regulated at the level of transcription by STAT3/STAT5 signaling [22] and at the post-translational level by phosphorylation and polyubiquitination $[23,24]$ to signal destruction by the proteasome. To test the dynamics of Mcl-1 levels in JAK2 ${ }^{\mathrm{V} 617 \mathrm{~F}}$ cells as compared to factor-dependent cells with wildtype JAK2, we transiently blocked signaling from JAK2 to STAT5 in both contexts. Consistent with previous reports [22,25] Mcl-1 levels dropped upon starvation of TF-1 erythroleukemia cells with wild type JAK2 and recovered upon re-stimulation with GM-CSF, correlating with the changes in STAT5 phosphorylation (Figure 5A). This was very similar to the drop seen in Mcl-1 levels in JAK2 ${ }^{\mathrm{V} 617 \mathrm{~F}}$-bearing SET-2 cells after 16 hours of treatment with NVP-BSK805 and re-induction of Mcl-1 after compound washout and release of the cells into fresh medium for 8 hours (Figure 5A). Treatment of SET-2 cells with NVP-BSK805 also led to a reduction of $\mathrm{Mcl}-1$ transcript levels, as assessed by 


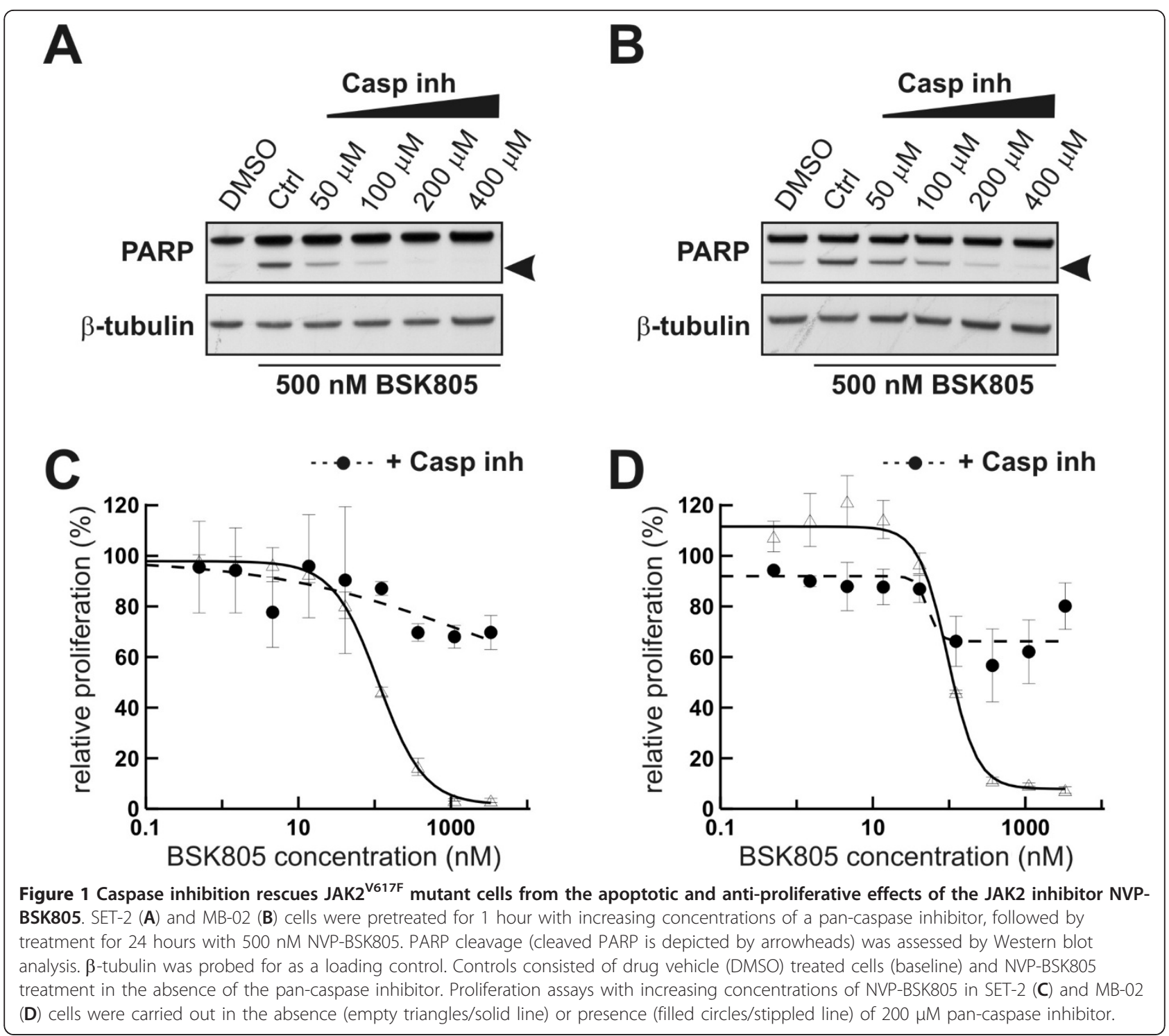

real-time qPCR (Additional file 1). Hence, the dynamic control of Mcl-1 levels in cells with wild type JAK2 [22] appears to be maintained in JAK2 ${ }^{\mathrm{V} 617 \mathrm{~F}}$ mutant cells.

As alluded to above, Bim-EL levels were readily detectable in SET-2 and MB-02 cell lines at baseline and did not increase appreciably upon JAK2 inhibitor treatment (Figure 2A and B). This was reminiscent of the modest changes in Bim-EL levels reported in IL-3 dependent mouse pro-B FL5.12 cells following IL-3 deprivation [26]. Thus, we investigated if the association of Bim with Mcl-1 and/or Bcl-xL $[15,16]$ would be impacted by JAK2 inhibition. Using SET-2 JAK2 ${ }^{\mathrm{V} 617 \mathrm{~F}}$ mutant cell extracts, we found that Mcl-1 co-immunoprecipitated with Bim and vice versa (Figure $5 \mathrm{~B}$ ). Importantly, despite a drop in total and immunoprecipitatable Mcl-1 levels in JAK2 ${ }^{\mathrm{V} 617 \mathrm{~F}}$ mutant cells treated with
NVP-BSK805, the relative ratio of Bim immunoprecipitated with Mcl-1 appeared constant or even increased compared to control cell extracts, indicating enhanced association of Bim and Mcl-1 upon JAK2 inhibition (Figure 5B). Interestingly, the amounts of Mcl-1 that could be immunoprecipitated from cells treated with NVP-BSK805 were already strongly reduced at the 4 hours time point (Figure 5B), at which total levels in whole cell extracts were not yet substantially lower compared to control cells (Figure 5C). The importance of $\mathrm{Bcl}-\mathrm{xL}$ in regulating survival of JAK2 ${ }^{\mathrm{V} 617 \mathrm{~F}}$ cells has already been recognized $[10,27,28]$, hence, we also assessed its interaction with Bim [16]. Similar to the results obtained with $\mathrm{Mcl}-1$, the relative amounts of $\mathrm{Bcl}-$ $\mathrm{xL}$ co-immunoprecipitated with Bim were comparable between extracts prepared from control and JAK2 


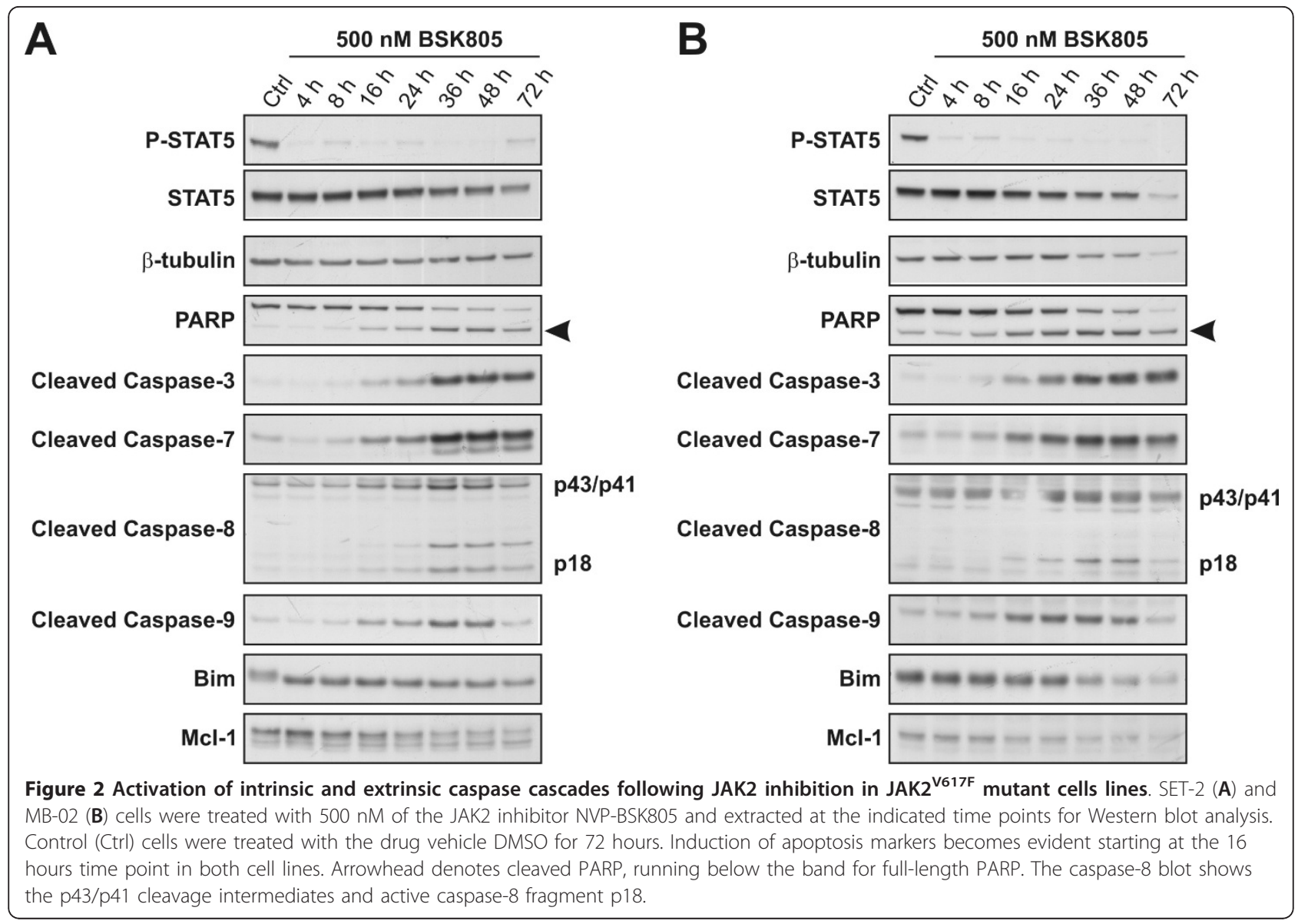

inhibitor treated cells (Figure 5D), despite reduced overall levels of Bcl-xL after 24 hours of drug treatment (Figure 5C). Using an antibody that recognizes an amino-terminal epitope of human Bax, there was a pronounced increase in the amounts of detergent-soluble Bax that could be immunoprecipitated after treatment of SET-2 cells with NVP-BSK805 (Figure 5D), while the total levels of Bax were unchanged (Figure 5C). Levels of detergent-soluble Bax that could be immunoprecipitated reached a plateau by 48 hours following JAK2 inhibition (Additional file 2). These findings imply either a change of Bax conformation, or a change of multiprotein complexes containing Bax, or both upon JAK2 inhibition. In support of changes in Bim/Bcl-xL/Bax complexes following JAK2 inhibition, lower amounts of Bax co-immunoprecipitated with Bcl-xL from cells treated with NVP-BSK805 (Figure 5D). Mcl-1 was not found to co-immunoprecipitate Bax (data not shown). Importantly, besides Bax also Bak needs to be activated to trigger mitochondrial cell death [11] and Mcl-1 has been described to antagonize Bak at the mitochondrial membrane [29]. Since both Bax and Bak are expressed in SET-2 cells (Figure 5C) we investigated Bak activation following JAK2 inhibition. To this end, we carried out co-immunoprecipitation experiments to study the interaction of Bak with either Mcl-1 or Bcl-xL. Unfortunately, these analyses were confounded by unspecific binding of Bak to the beads. Thus, we assessed Bak activation by flow cytometry using a conformation-specific Bak antibody [29]. These analyses revealed significant Bak activation in SET-2 cells starting at 24 hours following JAK2 inhibition (Figure 5E).

We noticed faster migration of Bim-EL in SDS-PAGE upon JAK2 inhibitor treatment (Figures 2, 3, 4, 5 and 6), indicative of changes in post-translational modification (s) [26]. Bim-EL contains a number of Ser/Thr-Pro consensus motif phosphorylation sites and phosphorylation on serine 69 by the MEK/ERK pathway was shown to regulate Bim activity/stability $[26,30]$. We assessed Bim Ser69 phosphorylation in SET-2 cells and found that this site was strongly modulated following JAK2 inhibition (Figure 6A), likely accounting for the changes seen in Bim-EL electrophoretic mobility, and in agreement with a recent report [21]. Phosphorylation on additional Ser/Thr-Pro sites has been reported to contribute to Bim-EL band-shifting in mouse pro-B FL5.12 cells [26]. 


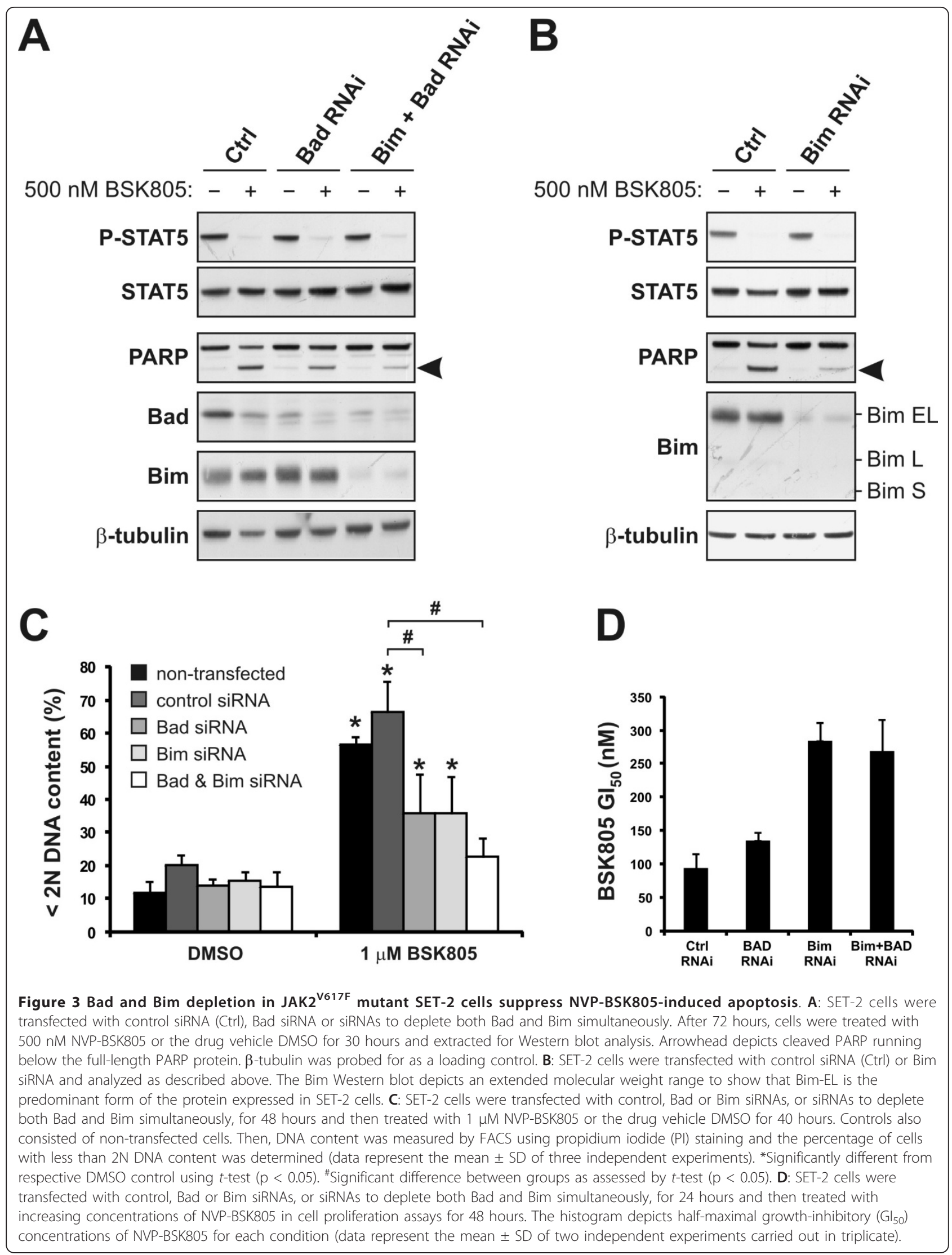




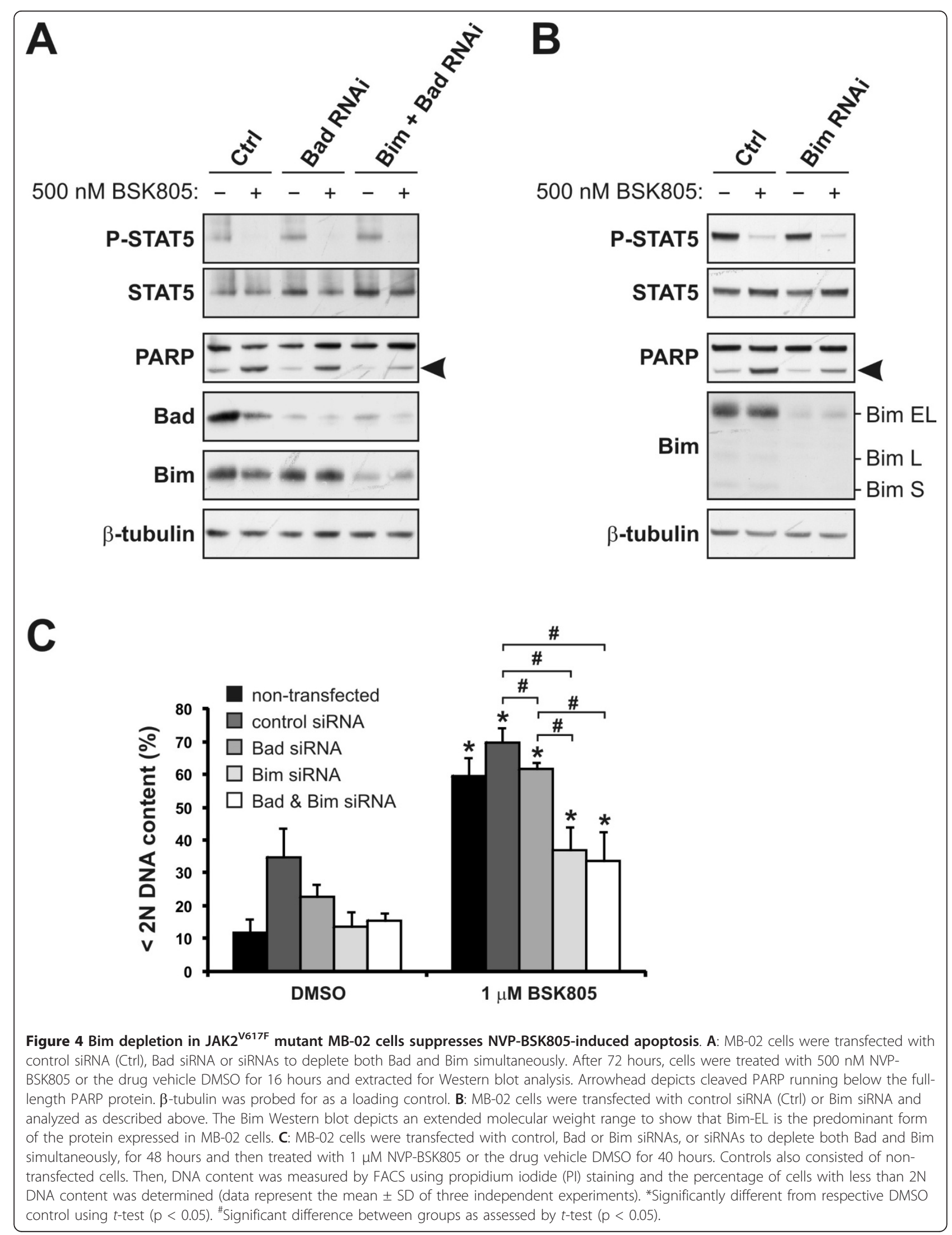




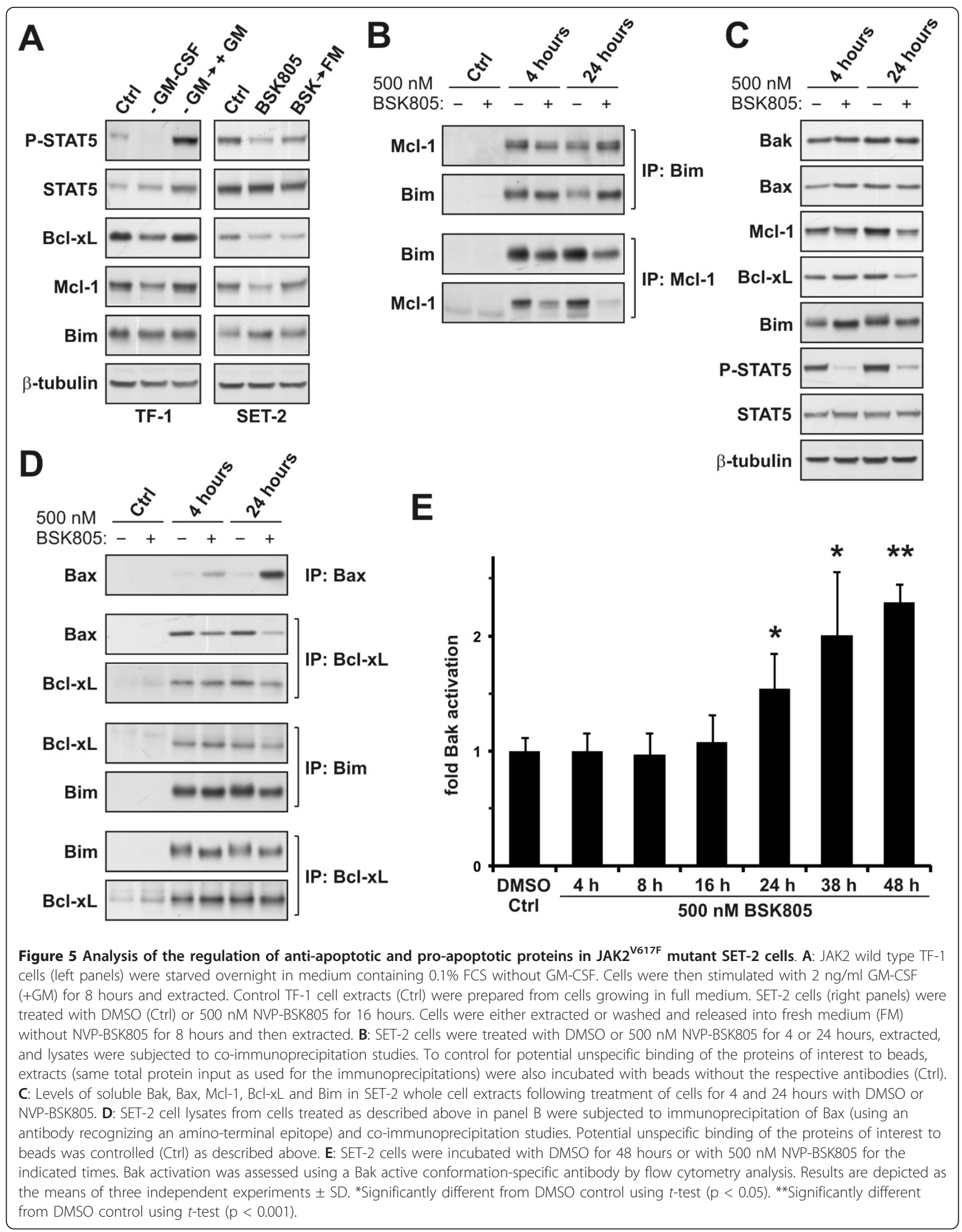




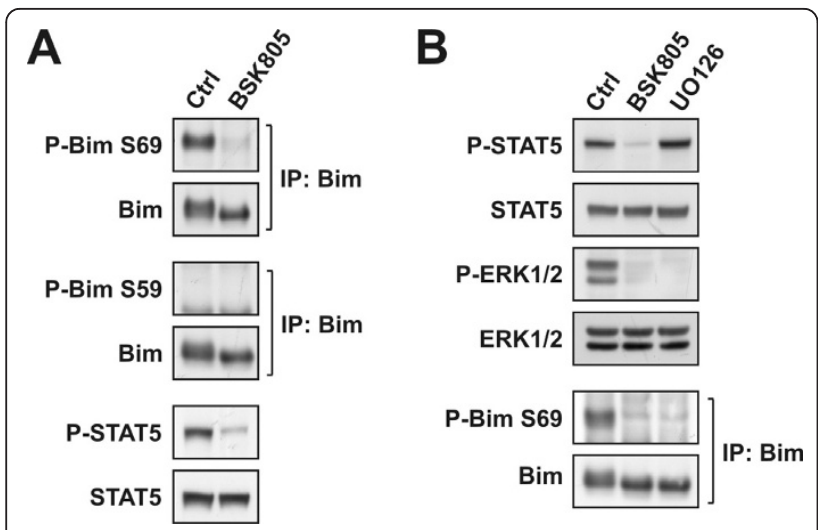

Figure 6 Analysis of Bim phosphorylation in JAK2 ${ }^{\mathrm{V} 617 \mathrm{~F}}$ mutant SET-2 cells. A: SET-2 cells were treated with DMSO or 500 nM NVPBSK805 for 24 hours. Bim was immunoprecipitated and levels of Bim-EL Ser69 as well as Ser59 phosphorylation were analyzed by Western blotting. Levels of P-STAT5 and total STAT5 were probed for as controls for the drug treatment. B: SET-2 cells were treated with DMSO, $500 \mathrm{nM}$ NVP-BSK805 or $10 \mu \mathrm{M}$ U0126 for 4 hours. Levels of P-STAT5, STAT5, P-ERK1/2 and ERK1/2 were assessed by Western blotting. Bim was immunoprecipitated and levels of Bim-EL Ser69 phosphorylation were detected by Western blotting.

However, we did not detect Bim Ser59 phosphorylation (Figure 6A) or Bim tyrosine phosphorylation (data not shown and [31]). In support of the MEK/ERK pathway mediating Bim phosphorylation, downstream of aberrant JAK2 signaling, treatment of SET-2 cells with the MEK inhibitor UO126 impacted Bim-EL electrophoretic mobility and Ser69 phosphorylation, comparable to that seen upon NVP-BSK805 treatment (Figure 6B).

\section{Mcl-1 is required for survival of JAK2 ${ }^{\mathrm{V} 617 \mathrm{~F}}$ cells}

To further test the extent to which Mcl-1 plays a role in JAK $2^{\mathrm{V} 617 \mathrm{~F}}$ mutant cell survival we used approaches involving pharmacological inhibition and RNAi. Incubation of SET-2 cells with sub-optimal concentrations of the pan-Bcl-2 family protein inhibitor obatoclax [32] in cell proliferation assays lowered the $\mathrm{GI}_{50}$ of NVPBSK 805 by 3 to 4 fold (Figure 7A). Since obatoclax also inhibits other Bcl-2 members, besides Mcl-1, and might exhibit off-target effects [33], we expanded on these results by specifically depleting Mcl-1 using RNAi. Importantly, Mcl-1 depletion increased apoptosis in JAK2 ${ }^{\text {V617F }}$ mutant SET-2 cells and sensitized the cells to NVP-BSK805-induced cell death as assessed by Western blot analysis and measuring the sub-G1 cell fraction by flow cytometry (Figure 7B and 7C). The latter finding was corroborated in cell proliferation assays. 24 hours after transfection of SET-2 cells with either non-targeting RNAi oligos or oligos directed towards the $\mathrm{Mcl}-1$ transcript, cells were treated with increasing concentrations of NVP-BSK805 for 48 hours. Notably, Mcl-1 depleted SET-2 cells had an approximately 4-fold lower
$\mathrm{GI}_{50}$ value as compared to SET-2 cells transfected with control oligos (Figure 7D). Similarly, obatoclax or Mcl-1 depletion by RNAi also strongly affected viability of MB-02 cells and sensitized them to JAK2 inhibition by NVP-BSK805 (data not shown).

\section{Discussion}

In malignant and normal cells the balance between proapoptotic and anti-apoptotic signals determines cell survival. The JAK2 ${ }^{\mathrm{V} 617 \mathrm{~F}}$ mutation was identified with high frequencies in the MPNs PV, ET as well as PMF, and is thought to provide mutant progenitor cells with a proliferation and survival advantage [7]. In the present study, we have focused on assessing the roles of the pro-apoptotic protein Bim and the anti-apoptotic protein $\mathrm{Mcl}-1$ in JAK2 ${ }^{\mathrm{V} 617 \mathrm{~F}}$ mutant cells. We report that Bim depletion by RNAi suppresses JAK2 inhibitor-induced apoptosis, while Mcl-1 depletion profoundly affects JAK2 ${ }^{\mathrm{V} 617 \mathrm{~F}}$ mutant cell viability and sensitizes cells to JAK2 inhibition. The BH3-only protein Bim plays an important role in hematopoietic homeostasis [34] and has been shown to be regulated by factors that activate JAK2 signaling $[26,35]$. Two cooperating pathways downstream of JAK2 activation have been reported to keep Bim activity in check; On one hand, PI3K/AKT signaling regulates the expression of the Bim gene via the forkhead transcription factor FOXO3A $[36,37]$, whereas on the other hand, MEK/ERK signaling promotes Bim phosphorylation on Ser69 and triggers its degradation by the proteasome [30]. Furthermore, it was recently found that Bim expression in erythroblasts is suppressed by the LRF transcription factor (itself being a direct target of GATA1) in the process of erythroid maturation [38]. Mcl-1 is a member of five anti-apoptotic proteins (Bcl-2, $\mathrm{Bcl}-\mathrm{xL}, \mathrm{Bcl}-\mathrm{W}, \mathrm{Mcl}-1$ and A1) that antagonize the proapoptotic proteins Bak and Bax [39]. Mcl-1 has a chief role in regulating the survival of hematopoietic stem cells and early hematopoietic progenitors [40]. Bcl-xL has an important role in protecting hematopoietic cells and maturing erythroid cells from cell death [41,42] and is a target gene of EpoR/JAK2 signaling [43]. Mcl-1 and $\mathrm{Bcl}-\mathrm{xL}$ sequester Bak and Bax until their displacement is promoted by the action of activated $\mathrm{BH} 3$-only proteins to trigger subsequent mitochondrial cell death [29].

Here we show that JAK2 inhibition in JAK2 $2^{\mathrm{V} 617 \mathrm{~F}}$ mutant cells led to post-translational changes in Bim that affected its interaction with other Bcl-2 family members. We detected enhanced association of Bim-EL with Mcl-1 upon JAK2 inhibition, seemingly consistent with earlier findings of apoptosis induction by serum withdrawal [16]. Furthermore, there was a sharp increase in the levels of immunoprecipitable Bax following JAK2 inhibition. In various settings, Bim-EL activation also involves loss of MEK/ERK pathway-mediated 




Ser69 phosphorylation, whereby Bim evades proteasomal degradation [16]. Loss of Bim-EL Ser69 phosphorylation following JAK2 inhibition in the JAK2 ${ }^{\mathrm{V} 617 \mathrm{~F}}$ mutant cell lines analyzed in this study likely plays a role in Bim activation, in agreement with a recent study by Will et al. [21]. However, Will et al. reported that Bim protein levels were up-regulated in JAK2 ${ }^{\mathrm{V} 617 \mathrm{~F}}$ mutant cells following JAK2 inhibition [21], which we did not see in our analyses. These differences might be attributable to different experimental settings. In fact, using factor-independent $\mathrm{Ba} / \mathrm{F} 3$ pro-B cells stably expressing EpoR and JAK2 ${ }^{\mathrm{V} 617 \mathrm{~F}}$ we also detected low basal levels of 
Bim-EL and a marked up-regulation upon JAK2 inhibition (data not shown), as found by Will et al. However, $\mathrm{Ba} / \mathrm{F} 3$ cells do not represent the hematopoietic lineage in which the JAK2 ${ }^{\mathrm{V} 617 \mathrm{~F}}$ mutation arises and regulation of Bim activity may be cell lineage-specific [26]. Taken together, our findings imply that Bim is in a latent complex with the Bcl-2 family pro-survival proteins Mcl-1 and Bcl-xL in viable JAK2 ${ }^{\text {V617F }}$ mutant cells. Both Mcl-1 and Bcl-xL govern survival of JAK2 ${ }^{\mathrm{V} 617 \mathrm{~F}}$ mutant cells by keeping Bax and Bak in check. In turn, JAK2 inhibition is postulated to affect Bim complexes such that Mcl-1 and $\mathrm{Bcl}-\mathrm{xL}$ are neutralized. This is proposed to drop anti-apoptotic activity in JAK2 ${ }^{\mathrm{V} 617 \mathrm{~F}}$ mutant cells below a critical threshold, unleashing Bak and Bax to drive mitochondrial cell death. Upon inhibition of JAK2/STAT signaling the expression of Bcl-xL [44] and Mcl-1 [25,45] is suppressed, along with subsequent reduction of $\mathrm{Bcl}-\mathrm{xL}$ and Mcl-1 protein levels, thereby contributing to the loss of pro-survival activity. Hence, as in CML [46-48] and FLT-3 mutant [49] AML cells, Bim is also emerging as a central cell death driver in JAK2 ${ }^{\mathrm{V} 617 \mathrm{~F}}$ mutant cells ([21], and this report).

Polycythemia vera patients with high JAK2 $2^{\mathrm{V} 617 \mathrm{~F}}$ mutant allele burden were described to have increased levels of Bcl-2 as well as Bcl-xL, and the Bcl-2/Bcl-W/ $\mathrm{Bcl}-\mathrm{xL}$ inhibitor ABT-737 was shown to preferentially inhibit proliferation and induce mitochondrial depolarization in JAK2 ${ }^{\mathrm{V} 617 \mathrm{~F}}$ mutant erythroblasts as compared to those from healthy subjects [9]. However, at the level of the individual MPN patient, Zeuner et al. did not detect a strict correlation between $\mathrm{Bcl}-2$ or $\mathrm{Bcl}-\mathrm{xL}$ expression and drug resistance, indicating that response to therapy may be determined by additional underlying anti-apoptosis mechanisms. Our findings suggest that combinations of JAK2 inhibitors with Bcl-2 family antagonists that also tackle Mcl-1, besides Bcl-xL $[21,50]$, merit further preclinical evaluation of the therapeutic potential for the treatment of cMPNs. Importantly, partial inhibition of Mcl-1 may be sufficient to sensitize cells to JAK2 inhibition. This could be important in order to minimize the impact on normal cells, such as e.g. on B and T lymphocytes, in which Mcl-1 plays a key role, as revealed by conditional knock-out studies [51]. Furthermore, it will be of particular interest to explore if combinations of JAK2 inhibitors with Bcl-2 family antagonists result in enhanced killing of the MPN mutant clone. Thus, follow-up experiments in suitable preclinical MPN animal models [52-54] would be important for proof of concept in vivo and to support the translation of potentially promising therapeutic modalities into the clinical setting. Encouragingly, clinical assessment of JAK inhibitors in MPN patients is underway [55], as well as intense drug discovery and development efforts to identify Mcl-1 antagonists $[32,56]$.

\section{Conclusions}

Bim and Mcl-1 were found to have opposing roles in regulating JAK2 ${ }^{\mathrm{V} 617 \mathrm{~F}}$ cell survival. JAK2 inhibition in JAK2 ${ }^{\mathrm{V} 617 \mathrm{~F}}$ mutant cells led to loss of Bim-EL Ser69 phosphorylation, with concomitant enhanced sequestration of the Bcl-2 family proteins $\mathrm{Mcl}-1$ and $\mathrm{Bcl}-\mathrm{xL}$. Consistent with a key role of Bim in regulating apoptosis in JAK2 ${ }^{\mathrm{V} 617 \mathrm{~F}}$ mutant cells, depletion of the BH3-only protein by RNAi markedly suppressed JAK2 inhibitorinduced cell death. Vice versa, RNAi-mediated Mcl-1 depletion sensitized JAK2 ${ }^{\mathrm{V} 617 \mathrm{~F}}$ mutant cells to JAK2 inhibition. Thus, further preclinical assessment of combinations of JAK2 inhibitors with Bcl-2 family antagonists in models of cMPNs is warranted and antagonizing Mcl-1, besides Bcl-xL, should be an integral part of such strategies.

\section{Additional material}

Additional file 1: Supplementary Figure S1 - Reduction of $\mathbf{M c l - 1}$
transcript levels following JAK2 inhibition by NVP-BSK805 in
JAK2 ${ }^{\text {V617F }}$ mutant SET-2 cells. SET-2 cells were treated for 4 and 8
hours with 500 nM NVP-BSK805. Control cells were treated with the drug
vehicle DMSO for 4 hours. Total RNA was isolated and Mcl-1 transcript
levels were determined in triplicate by real-time quantitative PCR. Mcl-1
mRNA levels were normalized to GAPDH mRNA levels in the respective
samples and means \pm SD were expressed as fold change compared to
the DMSO treated sample. Similar results were obtained in two
independent experiments.
Additional file 2: Time course of Bax activation following JAK2
inhibition by NVP-BSK805 in JAK2 ${ }^{\mathbf{V} 617 F}$ mutant cell lines. SET-2 (A)
and MB-02 (B) cells were treated with 500 nM of the JAK2 inhibitor NVP-
BSK805 and extracted at the indicated time points for
immunoprecipitation and Western blot analysis. Control (Ctrl) cells were
treated with the drug vehicle DMSO for 48 hours. Cells were extracted in
lysis buffer containing $1 \%$ CHAPS and Bax was immunoprecipitated using
an antibody that recognizes the amino-terminal epitope that is exposed
in the active conformation of Bax. Levels of immunoprecipitatable Bax at
the different time points following JAK2 inhibition were detected by
Western blotting. Western blot analysis was also used to assess levels of
Bax, PARP (cleaved PARP is depicted by arrowheads) and $\beta$-tubulin in
whole cell extracts. Results are representative of two independent
experiments.

\section{Acknowledgements}

The authors wish to thank Prof. Hans Drexler and Prof. Doris Morgan for the generous gift of SET-2 and MB-02 cell lines, respectively. The experimental advice from Dr. Débora Bonenfant and Dr. Johannes Voshol is greatly appreciated. Finally, we would like to thank Dr. Elisabeth Buchdunger and Dr. Francesco Hofmann for critical reading of the manuscript.

\section{Authors' contributions}

$J R$ and ZQ carried out the majority of the studies in JAK2 $2^{\mathrm{V} 617 \mathrm{~F}}$ mutant cell lines, participated in the design of experiments and helped draft parts of the manuscript. RA performed experiments in the cellular models and carried out Western blot analysis of Bim phosphorylation. DAG performed analyses of pro- and anti-apoptotic proteins. TR conceived the study, participated in 
the design of experiments and drafted the manuscript. All authors read and approved the final manuscript.

\section{Competing interests}

All authors are full-time employees of Novartis Pharma AG.

Received: 5 August 2010 Accepted: 19 January 2011

Published: 19 January 2011

\section{References}

1. Nelson ME, Steensma DP: JAK2 V617F in myeloid disorders: What do we know now, and where are we headed? Leuk Lymphoma 2006, 47:177-194.

2. Saharinen $P$, Vihinen $M$, Silvennoinen $O$ : Autoinhibition of Jak2 Tyrosine Kinase Is Dependent on Specific Regions in Its Pseudokinase Domain. Mol Biol Cell 2003, 14:1448-1459.

3. Levine RL, Wadleigh M, Cools J, Ebert BL, Wernig G, Huntly BJP, Boggon TJ, Wlodarska I, Clark JJ, Moore S, et al: Activating mutation in the tyrosine kinase JAK2 in polycythemia vera, essential thrombocythemia, and myeloid metaplasia with myelofibrosis. Cancer Cell 2005, 7:387-397.

4. Vannucchi AM: How do JAK2-inhibitors work in myelofibrosis: An alternative hypothesis. Leukemia Res 2009, 33:1581-1583.

5. Mesa R, Gale RP: Hypothesis: How do JAK2-inhibitors work in myelofibrosis. Leukemia Res 2009, 33:1156-1157.

6. Jamieson CH, Gotlib J, Durocher JA, Chao MP, Mariappan MR, Lay M, Jones C, Zehnder JL, Lilleberg SL, Weissman IL: The JAK2 V617F mutation occurs in hematopoietic stem cells in polycythemia vera and predisposes toward erythroid differentiation. Proc Natl Acad Sci USA 2006, 103:6224-6229.

7. Laubach JP, Fu P, Jiang X, Salter KH, Potti A, Arcasoy MO: Polycythemia vera erythroid precursors exhibit increased proliferation and apoptosis resistance associated with abnormal RAS and PI3K pathway activation. Exp Hematol 2009, 37:1411-1422.

8. Silva M, Richard C, Benito A, Sanz C, Olalla I, Fernandez-Luna JL: Expression of Bcl-x in Erythroid Precursors from Patients with Polycythemia Vera. N Engl J Med 1998, 338:564-571.

9. Zeuner A, Pedini F, Francescangeli F, Signore M, Girelli G, Tafuri A, De Maria R: Activity of the BH3 mimetic ABT-737 on polycythemia vera erythroid precursor cells. Blood 2009, 113:1522-1525.

10. Gozgit JM, Bebernitz G, Patil P, Ye M, Parmentier J, Wu J, Su N, Wang T, loannidis S, Davies A, et al: Effects of the JAK2 Inhibitor, AZ960, on Pim/ BAD/BCL-xL Survival Signaling in the Human JAK2 V617F Cell Line SET-2. J Biol Chem 2008, 283:32334-32343.

11. Adams JM, Cory S: The Bcl-2 apoptotic switch in cancer development and therapy. Oncogene 2007, 26:1324-1337.

12. Zhang B, Gojo I, Fenton RG: Myeloid cell factor-1 is a critical survival factor for multiple myeloma. Blood 2002, 99:1885-1893.

13. Kaufmann SH, Karp JE, Svingen PA, Krajewski S, Burke PJ, Gore SD, Reed JC: Elevated Expression of the Apoptotic Regulator Mcl-1 at the Time of Leukemic Relapse. Blood 1998, 91:991-1000.

14. Pissot-Soldermann C, Gerspacher M, Furet P, Gaul C, Holzer P, McCarthy C, Radimerski T, Regnier CH, Baffert F, Drueckes $P$, et al: Discovery and SAR of potent, orally available 2,8-diaryl-quinoxalines as a new class of JAK2 inhibitors. Bioorg Med Chem Lett 2010, 20:2609-2613.

15. Gomez-Bougie $P$, Bataille $R$, Amiot M: The imbalance between Bim and Mcl-1 expression controls the survival of human myeloma cells. Eur J Immunol 2004, 34:3156-3164.

16. Ewings KE, Hadfield-Moorhouse K, Wiggins CM, Wickenden JA, Balmanno K, Gilley R, Degenhardt K, White E, Cook SJ: ERK1/2-dependent phosphorylation of BimEL promotes its rapid dissociation from $\mathrm{Mcl}-1$ and Bcl-xL. EMBO J 2007, 26:2856-2867.

17. Baffert $F$, Régnier $\mathrm{CH}$, De Pover A, Pissot-Soldermann C, Tavares GA Blasco F, Brueggen J, Chène $P$, Drueckes $P$, Erdmann D, et al: Potent and Selective Inhibition of Polycythemia by the Quinoxaline JAK2 Inhibitor NVP-BSK805. Mol Cancer Ther 2010, 9:1945-1955.

18. Uozumi K, Otsuka M, Ohno N, Moriyama T, Suzuki S, Shimotakahara S, Matsumura I, Hanada S, Arima T: Establishment and characterization of a new human megakaryoblastic cell line (SET-2) that spontaneously matures to megakaryocytes and produces platelet-like particles. Leukemia 2000, 14:142-152.

19. Morgan DA, Gumucio DL, Brodsky I: Granulocyte-macrophage colonystimulating factor-dependent growth and erythropoietin-induced differentiation of a human cell line MB-02. Blood 1991, 78:2860-2871.
20. Adams JM: Ways of dying: multiple pathways to apoptosis. Genes Dev 2003, 17:2481-2495.

21. Will B, Siddiqi $T$, Jorda MA, Shimamura T, Luptakova $K$, Staber PB, Costa DB, Steidl $U$, Tenen DG, Kobayashi S: Apoptosis induced by JAK2 inhibition is mediated by Bim and enhanced by the BH3 mimetic ABT-737 in JAK2 mutant human erythroid cells. Blood 2010, 115:2901-2909.

22. Chao J-R, Wang J-M, Lee S-F, Peng H-W, Lin Y-H, Chou C-H, Li J-C, Huang H-M, Chou C-K, Kuo M-L, et al: mcl-1 Is an Immediate-Early Gene Activated by the Granulocyte-Macrophage Colony-Stimulating Factor (GM-CSF) Signaling Pathway and Is One Component of the GM-CSF Viability Response. Mol Cell Biol 1998, 18:4883-4898.

23. Maurer U, Charvet C, Wagman AS, Dejardin E, Green DR: Glycogen Synthase Kinase-3 Regulates Mitochondrial Outer Membrane Permeabilization and Apoptosis by Destabilization of MCL-1. Mol Cell 2006, 21:749-760.

24. Zhong Q, Gao W, Du F, Wang X: Mule/ARF-BP1, a BH3-Only E3 Ubiquitin Ligase, Catalyzes the Polyubiquitination of $\mathrm{Mcl}-1$ and Regulates Apoptosis. Cell 2005, 121:1085-1095.

25. Moulding DA, Quayle JA, Hart CA, Edwards SW: Mcl-1 Expression in Human Neutrophils: Regulation by Cytokines and Correlation With Cell Survival. Blood 1998, 92:2495-2502.

26. Harada H, Quearry B, Ruiz-Vela A, Korsmeyer SJ: Survival factor-induced extracellular signal-regulated kinase phosphorylates BIM, inhibiting its association with BAX and proapoptotic activity. Proc Natl Acad Sci USA 2004, 101:15313-15317.

27. Garcon L, Rivat C, James C, Lacout C, Camara-Clayette V, Ugo V, Lecluse Y, Bennaceur-Griscelli A, Vainchenker W: Constitutive activation of STAT5 and $\mathrm{BCl}-\mathrm{xL}$ overexpression can induce endogenous erythroid colony formation in human primary cells. Blood 2006, 108:1551-1554.

28. Zhao R, Follows GA, Beer PA, Scott LM, Huntly BJP, Green AR, Alexander DR Inhibition of the $\mathrm{BCl}-\mathrm{xL}$ Deamidation Pathway in Myeloproliferative Disorders. N Engl J Med 2008, 359:2778-2789.

29. Willis SN, Chen L, Dewson G, Wei A, Naik E, Fletcher Jl, Adams JM, Huang DCS: Proapoptotic Bak is sequestered by $\mathrm{Mcl}-1$ and $\mathrm{BCl}-\mathrm{xL}$, but not $\mathrm{BCl}-2$, until displaced by BH3-only proteins. Genes Dev 2005 19:1294-1305.

30. Luciano F, Jacquel A, Colosetti P, Herrant M, Cagnol S, Pages G, Auberger P: Phosphorylation of Bim-EL by Erk1//2 on serine 69 promotes its degradation via the proteasome pathway and regulates its proapoptotic function. Oncogene 2003, 22:6785-6793.

31. Wiggins $C M$, Band $H$, Cook SJ: $\mathrm{c}-\mathrm{Cbl}$ is not required for ERK1/2-dependent degradation of BimEL. Cell Signal 2007, 19:2605-2611.

32. Nguyen $M$, Marcellus RC, Roulston A, Watson M, Serfass L, Murthy Madiraju SR, Goulet D, Viallet J, Bélec L, Billot X, et al: Small molecule obatoclax (GX15-070) antagonizes MCL-1 and overcomes MCL-1mediated resistance to apoptosis. Proc Natl Acad Sci USA 2007, 104:19512-19517.

33. Tse C, Shoemaker AR, Adickes J, Anderson MG, Chen J, Jin S, Johnson EF, Marsh KC, Mitten MJ, Nimmer P, et al: ABT-263: A Potent and Orally Bioavailable Bcl-2 Family Inhibitor. Cancer Res 2008, 68:3421-3428

34. Bouillet P, Metcalf D, Huang DC, Tarlinton DM, Kay TW, Köntgen F, Adams JM, Strasser A: Proapoptotic Bcl-2 Relative Bim Required for Certain Apoptotic Responses, Leukocyte Homeostasis, and to Preclude Autoimmunity. Science 1999, 286:1735-1738.

35. Abutin RM, Chen J, Lung TK, Lloyd JA, Sawyer ST, Harada H: Erythropoietininduced phosphorylation/degradation of BIM contributes to survival of erythroid cells. Exp Hematol 2009, 37:151-158.

36. Dijkers PF, Medema RH, Lammers J-W, Koenderman L, Coffer PJ: Expression of the pro-apoptotic $\mathrm{BCl}-2$ family member Bim is regulated by the forkhead transcription factor FKHR-L1. Curr Biol 2000, 10:1201-1204.

37. Essafi A, Fernandez de Mattos S, Hassen YAM, Soeiro I, Mufti GJ, Thomas NSB, Medema RH, Lam EWF: Direct transcriptional regulation of Bim by FoxO3a mediates STI571-induced apoptosis in Bcr-Ablexpressing cells. Oncogene 2005, 24:2317-2329.

38. Maeda T, Ito K, Merghoub T, Poliseno L, Hobbs RM, Wang G, Dong L, Maeda M, Dore LC, Zelent A, et al: LRF Is an Essential Downstream Target of GATA1 in Erythroid Development and Regulates BIM-Dependent Apoptosis. Dev Cell 2009, 17:527-540.

39. Gélinas $C$, White E: BH3-only proteins in control: specificity regulates MCL-1 and BAK-mediated apoptosis. Genes Dev 2005, 19:1263-1268. 
40. Opferman JT, Iwasaki H, Ong CC, Suh H, Mizuno S, Akashi K, Korsmeyer SJ: Obligate Role of Anti-Apoptotic MCL-1 in the Survival of Hematopoietic Stem Cells. Science 2005, 307:1101-1104.

41. Motoyama N, Wang F, Roth KA, Sawa H, Nakayama K, Nakayama K, Negishi I, Senju S, Zhang Q, Fujii S, Loh DY: Massive cell death of immature hematopoietic cells and neurons in Bcl-x-deficient mice. Science 1995, 267:1506-1510.

42. Wagner KU, Claudio E, Rucker EB, Riedlinger G, Broussard C, Schwartzberg PL, Siebenlist U, Hennighausen L: Conditional deletion of the $\mathrm{BCl}-\mathrm{x}$ gene from erythroid cells results in hemolytic anemia and profound splenomegaly. Development 2000, 127:4949-4958.

43. Richmond TD, Chohan M, Barber DL: Turning cells red: signal transduction mediated by erythropoietin. Trends Cell Biol 2005, 15:146-155.

44. Quelle FW, Wang J, Feng J, Wang D, Cleveland JL, Ihle JN, Zambetti GP: Cytokine rescue of p53-dependent apoptosis and cell cycle arrest is mediated by distinct Jak kinase signaling pathways. Genes Dev 1998, 12:1099-1107.

45. Puthier D, Bataille R, Amiot M: IL-6 up-regulates Mcl-1 in human myeloma cells through JAK/STAT rather than Ras/MAP kinase pathway. Eur J Immunol 1999, 29:3945-3950.

46. Kuribara R, Honda H, Matsui H, Shinjyo T, Inukai T, Sugita K, Nakazawa S, Hirai H, Ozawa K, Inaba T: Roles of Bim in Apoptosis of Normal and BcrAbl-Expressing Hematopoietic Progenitors. Mol Cell Biol 2004, 24:6172-6183.

47. Aichberger KJ, Mayerhofer M, Krauth M-T, Vales A, Kondo R, Derdak S, Pickl WF, Selzer E, Deininger M, Druker BJ, et al: Low-Level Expression of Proapoptotic Bcl-2-Interacting Mediator in Leukemic Cells in Patients with Chronic Myeloid Leukemia: Role of BCR/ABL, Characterization of Underlying Signaling Pathways, and Reexpression by Novel Pharmacologic Compounds. Cancer Res 2005, 65:9436-9444.

48. Kuroda J, Puthalakath H, Cragg MS, Kelly PN, Bouillet P, Huang DCS, Kimura S, Ottmann OG, Druker BJ, Villunger A, et al: Bim and Bad mediate imatinib-induced killing of $\mathrm{Bcr} / \mathrm{Abl}+$ leukemic cells, and resistance due to their loss is overcome by a BH3 mimetic. Proc Natl Acad Sci USA 2006, 103:14907-14912.

49. Nordigarden A, Kraft M, Eliasson P, Labi V, Lam EWF, Villunger A, Jonsson JI: BH3-only protein Bim more critical than Puma in tyrosine kinase inhibitor-induced apoptosis of human leukemic cells and transduced hematopoietic progenitors carrying oncogenic FLT3. Blood 2009, 113:2302-2311.

50. Dai Y, Grant S: Targeting Multiple Arms of the Apoptotic Regulatory Machinery. Cancer Res 2007, 67:2908-2911.

51. Opferman JT, Letai A, Beard C, Sorcinelli MD, Ong CC, Korsmeyer SJ: Development and maintenance of $B$ and $T$ lymphocytes requires antiapoptotic MCL-1. Nature 2003, 426:671-676.

52. James C, Ugo V, Le Couedic J-P, Staerk J, Delhommeau F, Lacout C, Garcon L, Raslova H, Berger R, Bennaceur-Griscelli A, et al: A unique clonal JAK2 mutation leading to constitutive signalling causes polycythaemia vera. Nature 2005, 434:1144-1148.

53. Wernig G, Kharas MG, Okabe R, Moore SA, Leeman DS, Cullen DE, Gozo M, McDowell EP, Levine RL, Doukas J, et al: Efficacy of TG101348, a Selective JAK2 Inhibitor, in Treatment of a Murine Model of JAK2V617F-Induced Polycythemia Vera. Cancer Cell 2008, 13:311-320.

54. Pikman Y, Lee BH, Mercher T, McDowell E, Ebert BL, Gozo M, Cuker A, Wernig G, Moore S, Galinsky I, et al: MPLW515L Is a Novel Somatic Activating Mutation in Myelofibrosis with Myeloid Metaplasia. PLoS Med 2006, 3:e270.

55. Verstovsek S: Therapeutic Potential of Janus-activated Kinase-2 Inhibitors for the Management of Myelofibrosis. Clin Cancer Res 2010, 16:1988-1996.

56. Lessene G, Czabotar PE, Colman PM: BCL-2 family antagonists for cancer therapy. Nat Rev Drug Discov 2008, 7:989-1000.

\section{Pre-publication history}

The pre-publication history for this paper can be accessed here: http://www.biomedcentral.com/1471-2407/11/24/prepub

doi:10.1186/1471-2407-11-24

Cite this article as: Rubert et al: Bim and $\mathrm{Mcl}-1$ exert key roles in regulating JAK2 ${ }^{\mathrm{V} 617 \mathrm{~F}}$ cell survival. BMC Cancer 2011 11:24.

\section{Submit your next manuscript to BioMed Central and take full advantage of:}

- Convenient online submission

- Thorough peer review

- No space constraints or color figure charges

- Immediate publication on acceptance

- Inclusion in PubMed, CAS, Scopus and Google Scholar

- Research which is freely available for redistribution

Submit your manuscript at www.biomedcentral.com/submit
C Biomed Central 